Kjell Askildsen (f. 1929) regnes som en av de største prosaforfattere i norsk etterkrigslitteratur. Han debuterte med novellesamlingen Heretter følger jeg deg helt hjem i 1953. Askildsen har fått Kritikerprisen to ganger, for novellesamlingene Thomas F's siste nedtegnelse til almenheten (1983) og Et stort øde landskap (1991). I 2009 ble Askildsen tildelt Svenska Akademiens nordiske pris. Han har også blitt tildelt blant annet Aschehougprisen, Doblougprisen og Brages hederspris. Sommeren 2006 kåret Dagbladet novellesamlingen Thomas F's siste nedtegnelser til almenheten til den beste norske boken utgitt de siste 25 årene. I 2011 mottok Askildsens Aase Byes legat. Kjell Askildsens bøker er oversatt til over 20 språk, blant dem engelsk, tysk, fransk og italiensk. 


\section{Hva binder til livet? Et intervju med Kjell Askildsen Av Arine Thorvik}

«Vi bor i et brunt hus med blå kanter», lyder tekstmeldingen som tikker inn mens jeg plotter adressen på GPS. «Kiør inn porten. Velkommen.»

Jeg parkerer, og Gina tar imot. I entreen høres klassisk musikk. Jeg er spent på å møte mannen som skrev Heretter folger jeg deg helt hiem, novellesamlingen jeg leste i ungdommen. Så står han i døråpningen. Kjell Askildsen er eldre enn jeg husker fra bildet i litteraturhistorien. Språket er avslepet sørlandsk, dempet, men både stemmen og skikkelsen formidler en stille autoritet.

Først spiser vi Ginas eplekake. Som halvt arendalitt forsøker jeg meg med en replikk om sørlendingers temperament. Vi finner tonen. Det står en byste av ham på Mandal bibliotek, samme sted som novellesamlingen var uønsket for seksti år siden.

Vi går inn i stuen, et luftig rom med diskret kunst. Interviuet kan begynne.

- Selvmord er nå engang tema for dette fagbladet. Husker du hvordan man anså det $i$ din barndom?

- Selvmord var aldri på tale i mitt barndomshjem. Jeg erindrer ikke at noen begikk selvmord. Eller fortalte om det. Det var ikke et tema.

- Historisk sett har det vært religios fordømmelse -

- Ja, det er klart, du kom til helvete hvis du tok ditt eget liv. Det var en helt opplagt sak.

- Ifølge biografien har du droftet selvmord i en roman du fikk i retur fra forlaget.
- Jeg hadde skrevet om å hjelpe en venn over grensen. Denne sendte jeg til mitt forlag, som da var Aschehoug. Midt på 6o-tallet må det ha vært, eller mot slutten av 6o-tallet. Det var en tykk bok, særlig til meg å være. Så sendte jeg den inn, og det kom ikke noe svar. Da jeg endelig fikk den tilbake, sto det bare at «dette så de seg ikke tjent med å utgi». Jeg ble så sint. Jeg brente pakken, uten å ville ha noe mer med saken å giøre. Puttet den rett inn i ovnen.

- Hva var ditt budskap i denne romanen?

- Budskapet var at man skulle hjelpe en som ikke fant å ha noe mer å leve for, og som samtidig hadde lidelser. Omtrent samtidig gikk det en debatt om å hjelpe en annen ut av livet, som jeg stilte meg helt bak som person. Jeg ødela manuskriptet, og dermed mistet jeg argumentet for å anklage forlaget. Jeg kan ikke bevise noe som helst om beveggrunnene for at de ikke ville ha den, annet enn at temaet var for kontroversielt. På den tiden var jeg i ferd med å skrive neste bok, en novellesamling, og som jeg anså for å være mer verdifull enn boka jeg brente.

- Men for å vende tilbake til din barndoms Mandal: I biografien står at du satt på konditori og leste den franske filosofen Albert Camus og essayet Myten om Sisyfos -

- Ja, det stemmer. Vi var en gruppe gymnasiaster som møttes på «Skagestads konditori» hver dag, så å si. Og da hadde vi lesestoff som vi drøftet, ikke bare Camus. Det utkom på den tiden, på 5o-tallet, bøker som var essayistiske. 
- Upopulære skrifter?

- Nettopp: Upopulære skrifter. De var det flere av oss som leste, og lot gå på omgang.

- Hvordan ble dere ansett i lokalmiliøet?

- Det var bare vi som var der. Vi okkuperte det innerste rommet i kafeen, drakk kaffe og rokte pipe. Etter hvert vokste vi fra hverandre.

- Camus' essay begynner med en kient setning om at «det finnes bare ett virkelig alvorlig filosofisk problem: selvmordet». Hvis et selvmord skal inn i det skrevne, så må årsakene forklares. For ellers blir det bare å leke, en feilvurdering av hva litteratur skal være. Men man kan innvende at han ikke skriver om selvmord, men mer om hva som gior livet verd å leve. Hva som egentlig binder oss til livet.

- Ja, det synes jeg er helt logisk. Det er å lete etter punktene som holder en i live.

- I så fall kan man sporre om han bruker selvmord som utgangspunkt for en filosofisk drofting som ikke har så mye med det medisinske selvmordet å giore. Noe liknende har du tematisert i en novelle som heter Ventetid. Der er du inne på at det kan bli et for enkelt litterært grep, dette at et skiønnlitterært verk ender i selvmord.

- Ja, det kan det selvfølgelig lett bli, hvis det ikke står i en sammenheng. At det bare blir en påstand, fratatt bakgrunnsmotiv og sammenheng.

- Ville det vært mer utfordrende for Ibsen å la Hedda Gabler leve, og da i et frustrert ekteskap?

- Nei, da hadde han ikke skrevet det. Nå skriver jo Ibsen veldig godt, da.

- Vi skal ikke kritisere Ibsen -

- He-he, nei, det skal vi ikke. Men ellers kan all litteratur bebreides, i og for seg, på det samme grunnlag. At historien ikke er nær nok virkeligheten. Hvis et selvmord skal inn i det skrevne, så må årsakene forklares. For ellers blir det bare å leke, en feilvurdering av hva litteratur skal være.

- For å returnere til Camus' essay, så gjennomgår han posisioner som muligens kan gi mening i en absurd verden. Et sted nevner han en fransk skuespillerinne fra 1700-tallet som på slutten av sitt liv onsket å gå til skrifte, men nektet å avsverge sitt yrke, som kirken satte som premiss. Og da skriver Camus at ved å være trofast viste hun sin storhet. Hva tenker du? Din holdning til kirken har preget mye av ditt liv-

- Veldig mye, og da til gudstroen. Selve kirken har vært mer overflødig for meg, for den er bare hensiktsmessig for noen mennesker. Alle religioner har de samme tendensene. Jeg har vært imot gudstroen fra jeg var rundt 15-16 år. Og det med god grunn, for den giorde så mye vondt. Ikke til å begynne med, for da var det en selvfølge, med så troende foreldre som jeg hadde. Men så det gikk opp for meg at det var bare absurd det jeg hadde lært. Av min far, som for så vidt var fornuftig, men helt spikret fast i tanken på korset. Og helvetet. Dette klarte jeg å løsrive meg fra. Bortsett fra da jeg selv var i en slags utslått situasion. Ikke at det rablet for meg, men det begynte å bli utålelig i en periode. Det hadde noe med skilsmisse og skyld å giøre. Og det hadde med anger å giøre, som ikke var religiøs på noe som helst plan, men som var like sterk. Da våknet jeg med mareritt, om å være midt i en oppbrenning. Det var levningene etter oppdragelsen.

- Nå som du er gammel, og det er begrenset hvor mange år du har igien å leve - hva tenker du da om religionen?

- Akkurat som jeg har tenkt i boka, og alt jeg har skrevet. For meg er den en uforståelig absurditet. Med gud og paradiset. Det er så latterlig barnslig for meg.

- Så det har du holdt fast ved. Slik som skuespillerinnen, som nektet å avsverge sitt yrke.

- Absolutt. Det er så soleklart for meg.

- Tilbake til Camus, så snakker han om at det kan gi en meningsopplevelse å kiempe for en sak. Du har jo hatt kamper i ditt liv, som dette politiske engasjementet.

- Det var ikke kamporientert, egentlig. For meg var ikke kjernen en eller annen spesiell retning. Da jeg var maoist, visste jeg ingenting om hva Mao betydde i den asiatiske tilværelse. Som det fikk da Mao viste ansikt, og begynte utryddelse. Jeg leste ikke engang den røde boka. Det hadde noe med den samme rettferdighetssans som for eksempel Arbeiderpartiet sto for i min oppvekst. Og som jeg i denne perioden syntes de hadde odelagt kjernen i. Og dermed kom jeg og flere andre på venstresida til at Arbeiderpartiet ikke var som det skulle være. Og der står jeg fremdeles. Men jeg graderer jo på en annen måte enn i den litt heftige perioden med AKP.

- Noe du vil fortelle fra den tiden?

- Jeg giorde ting der, som var mot min natur. For eksempel sto jeg og solgte Klassekampen på torget. Men det orket jeg ikke lenger, og der kommer ens eget sinn inn, jeg orket ikke å stå på Grønlands torg med avisen og selge den. Det var ikke min natur, så det sa jeg fra meg. Og de skiønte det. Jeg forklarte hvordan det var. Jeg hadde nerver til det, men jeg hadde ikke sinn til å giøre det. Jeg var helt enig i det som sto i avisen, det aller meste i hvert fall. Men jeg kunne ikke stå der og være selger. Det klarte jeg ikke. Men jeg var en budbringer for avisen, leverte på visse adresser rundt ostkanten i Oslo, til folk som ikke ville stå frem som AKP-ere. Så det giorde jeg, og det sluttet jeg ikke med.

- Hvordan ser du nå på denne politiske perioden?

- Som en god tid. Den er borte nå. Det var en god tid for meg, jeg har ikke noe jeg angrer på. Selv ikke at jeg ikke hadde sinn til å selge avisen. Jeg har fulgt til det tok slutt, og jeg gikk ut av politikken. 
- Det hores ut som engasjementet ga mening?

- Absolutt, det vil jeg ikke underslå på noen som helst måte. Det var noe veldig viktig i det for meg. Så kan det være litt vanskelig å si hva det besto i, men det var nok et fellesskap. Hvis man vil være ondsinnet, så kan man kanskje si at det var en slags gienfødelse av det jeg hadde gått ut av tidligere. Det var kirken, ja egentlig bedehuset, det var ikke kirken i seg selv. Jeg meldte meg ut av statskirken. Det var det forste jeg giorde, som ganske ung, da jeg var gammel nok til å melde meg ut.

- Det er en tredie posisjon som Camus nevner, som han kaller for Don Juan. Den skikkelsen forekommer jo i litteraturen, og blir oftest sett på som moralsk forkastelig. Men Camus skriver at han tenker seg Don Juan som en stor vismann. Han har forstått at livet er grunnleggende absurd, men han tar for seg av de gleder somer. - Forholdet til kvinner og erotikk har jeg inntrykk av betyr mye i ditt forfatterskap?

- Det giør det nok. Det giør det i alles liv, i ditt liv også.

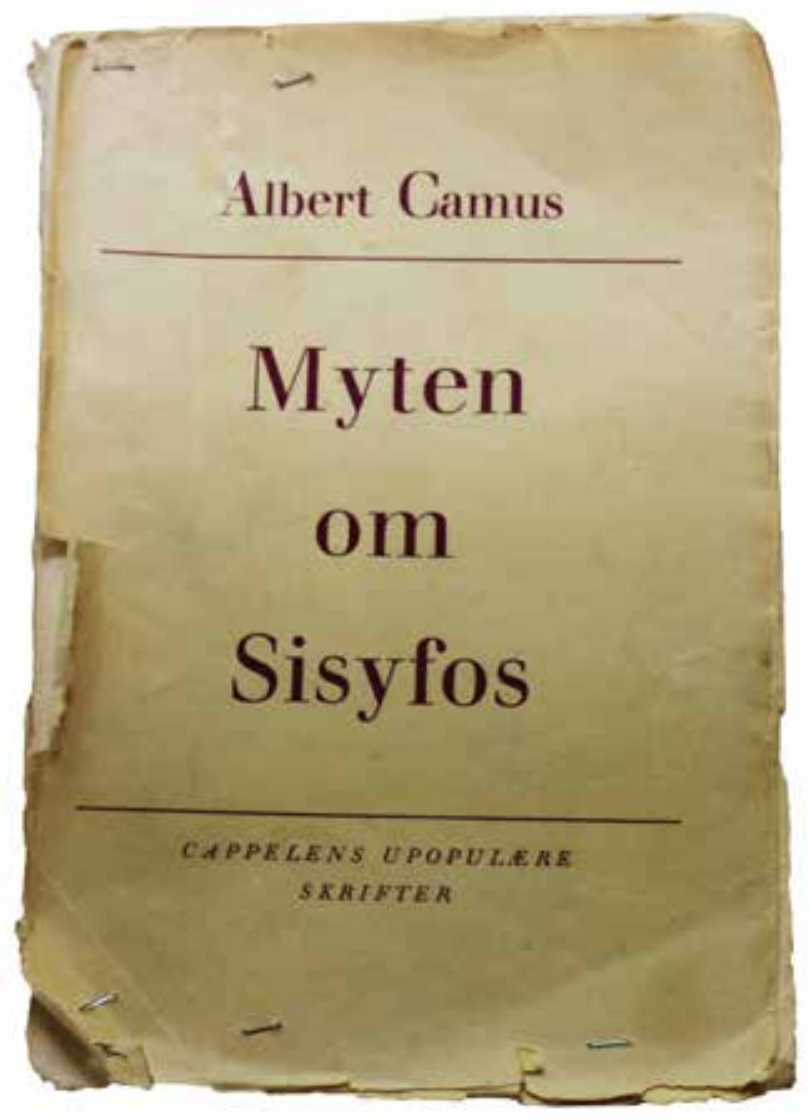

Den franske filosofen Albert Camus (1913-60) utga i 1942 essayet Myten om Sisyfos (Le Mythe de Sisyphe), der han tar for seg eksistensens grunnleggende absurditet, men også posisjoner som kan gi individet en opplevelse av mening.
Det giør det jo. Men hva mener han mer konkret?

- Kanskje at noen finner en mening i absurditeten ved stadige erobringer, kjærlighetsforhold.

- Ja, det tror jeg gierne. Det kan jo være mange gode øyeblikk. Men å erobre, det er ikke nødvendigvis det man giør, det er den andre som gir seg hen til det. Du kan ikke giøre noe med et annet menneske som det mennesket ikke vil. Det er den moralske bygningen som man bor i.

- Men Camus synes å mene at det er andre handlinger som kan gi en mer intens meningsopplevelse, som når han snakker om å skape noe.

- Ja, definitivt. Det er noe av det mest tilfredsstillende jeg kan tenke meg, det er å få det til, og vite at jeg har fått det til.

- Som forfatter, som skapende?

- Ja. Og det største tapet jeg har hatt i livet er å tape synet. Jeg har ikke mistet evnen, men hjelpemidlet til å få det ned på papir. Det er ikke mulig, for jeg kan ikke lese den foregående setningen. Dette har gått helt i stykker, det er helt umulig å fortsette med det som betydde noe. Det finnes forfattere som kunne skrevet det inn på et bånd. Men jeg er ikke der. Så det var et veldig tap.

- Du skriver i en novelle, Ventetid, at det er noe paradoksalt ved å hevde som i Predikeren at alt er forgiengelig og jag etter vind. A annonsere dette kan paradoksalt nok gi en tilfredsstillelse.

- Å, den novellen har jeg ikke lest på lang tid. Den hører ikke med til det som jeg er veldig glad for å ha skrevet. Men jeg sier ikke at den ikke har noe for seg. - Men den har en svakhet: Han brukte en sikkerhetsnål til å tappe blod. Jeg tror ikke det lar seg giøre.

- En kjent novelle heter En plutselig frigiørende tanke.

- Ja. Jeg er glad for den. Fornøyd.

- Som mye du har skrevet er den «knapp i stilen». Det er korte og rene setninger, en kunne si «som hugget i stein».

- Ja. Jeg har alltid vært veldig påpasselig med ikke å si alt. Det må ikke være noe overflødig, men slik at det blir forstått. Og det skal være våkne lesere.

- Forfatteren Harold Pinter sier i et foredrag at han har et ambivalent forhold til ord. Vi overstrommes av ord hele tiden.

- Jeg har oversatt en del Pinter for Nationaltheatret. Jeg liker ham. Jeg synes han ikke sier for mye. At det er for mange ord i verden, har jeg selv skrevet om i en novelle. Det er altfor mange ord i verden. «Den som sier mye, har ikke sine ord i behold.» Det er mitt utsagn.

- En plutselig frigiørende tanke har en doktor som hovedperson. For meg virker det som om det er en ambivalens. På den ene siden vil han ikke livet mer. Likevel ser han frem til å mote dommeren i parken. Så det er litt engasjement et sted?

- Ja visst. Dette møtet med dommeren, det er det siste som doktoren har fått i livet sitt. En klok mann, etter hans mening. Og dommeren synes ikke selv at han kunne be ham om å la være å reise, det er ikke noe sånt forhold mellom dem. Men når doktoren forteller ham at han skal rei- 


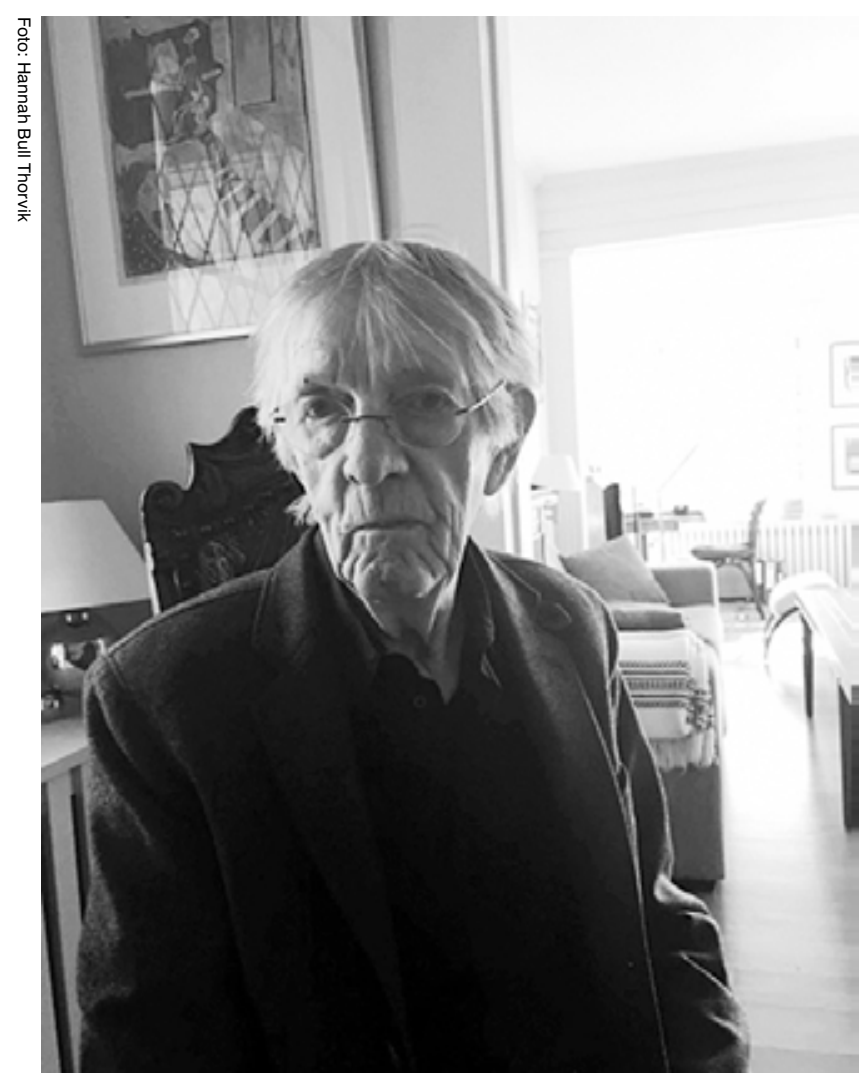

Det er altfor mange ord i verden. «Den som sier mye, har ikke sine ord i behold.» Det er mitt utsagn.

se, da vet doktoren at han ikke vil mer. Hans liv er tomt. Men det lå et engasjement der. Han sier det ikke direkte, så vidt jeg husker. Men det ga ham en glede.

- Ia, han sier at han «nesten gledet seg» til å mote dommeren -

- Ja, nemlig.

- Og så sier han også at denne selvoppholdelsesdriften kan være en plage -

- Ja. Han har hatt et tomt liv, du hører det jo etter de forste setningene. Og nå er det blitt for tomt. Doktoren er en gammel mann, og han visste at han ville dø. Det er så lenge siden jeg har skrevet den. Det står ingen ting om hvordan han vil dø.

- Nei. Men det var en plutselig frigiørende tanke.

- Ja.

- Det er en filosof som heter Schopenhauer, ham kjenner du sikkert?

- He-he, ja. Han var også litt muggen.

- Som sier noe om at selvmorderen vil livet, men er utilfreds med livsbetingelsene. Det ligger noe paradoksalt i selvmordet, for det uttrykker at man hadde forventninger til livet. Finnes det noe livsbejaende hos doktoren?

- Det kan man si. Men han dør jo. Jeg har iallfall tenkt at han giør det. Men det kan jo skje en merkelig ting, eller noe sånt. - Jeg er glad for den novellen. Da jeg begynte å skrive på den, så hadde jeg ikke hans død i tankene i det hele tatt. Men det er sånn jeg arbeider. Jeg kan ikke tenke fremover. Jeg tenker bare så langt som det jeg har skrevet ned. Og det er ikke så mange setninger av gangen. Eller om dagen.

- Nei. Du bruker tid.

- Teg bruker tid, ja.

- Du er gammel og har mistet mye av synet. Hva vil du si binder deg til livet? Hva er det som gir mening?

- Selv om jeg har mistet lese- og skrivesynet, kan livet være godt. Og jeg har et godt liv. Jeg merker jo at jeg har en alder. Og jeg merker at jeg ikke husker like godt som jeg giorde før. Det er så mange positive ting som kan sies, selv om jeg nå ikke er yrkesutøver. Jeg har mange minner.

- Jeg var glad for Kjell Askildsen. Et liv. Boken Alf van der Hagen skrev om meg. Etter at den kom ut, har Alf og jeg snakket sammen om boken på litteraturfestivaler syv steder i landet.

Kjell Askildsen har reist seg, og ser ut giennom et blankpusset vindu. Det er vårlys utenfor.

- Jeg har prøvd å bruke livet. Noen ganger er det ting som jeg har angret på. Som har giort vondt, fordi jeg har giort andre vondt også. Som gammel er jeg helt rolig. Nå er jeg seksogåtti på det nærmeste. Det finnes ikke et fnugg av frykt i meg for å dø. Ikke det aller minste. Så der er jeg helt fri. Jeg er glad for det.

- Jeg har venner, mange venner. Og kan høre musikk. Opplever naturen og årstidene. Det blir vår, så sommer, så høst. Det er mange gleder.

Vi går til entreen, der det fortsatt høres klassisk piano. Er det Schubert? Jeg sier farvel, og han som skrev Heretter folger jeg deg helt hiem geleider meg trygt ut av oppkjørselen. I speilet ses en mann foran et brunt hus med blå kanter. Hånden løftes til hilsen, så er han borte.

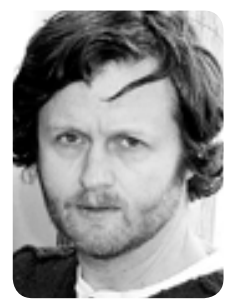

ARNE THORVIK er psykiater og avd.overlege ved Psykiatrisk fylkesavd. sykehuset i Vestfold. Han disputerte for PhD-grad i 2011 med en avhandling bl.a. basert på dybdeintervjuer av pasienter med suicidproblematikk. Thorvik er medlem av redaksjonskomiteen ved Suicidologi. 